\title{
Agroclimatic Zoning for the Palm Euterpe edulis M. in São Paulo State, Brazil
}

\author{
Ricardo de Lima Vasconcelos ${ }^{1,2}$, Luís Augusto Gomes Rocha ${ }^{1}$, Renan Lima de Sousa ${ }^{1}$, \\ Jéssica Maiara de Souza Ferrari ${ }^{1}$, Rafael dos Santos Lima ${ }^{1}$, Anice Garcia ${ }^{2}$, Luís Roberto Almeida Gabriel Filho ${ }^{3}$ \\ \& Camila Pires Cremasco Gabriel ${ }^{3}$ \\ ${ }^{1}$ Universidade Estadual Paulista, Botucatu, Brazil \\ ${ }^{2}$ Faculdade Dr. Francisco Maeda, Ituverava, Brazil \\ ${ }^{3}$ Universidade Estadual Paulista, Tupã, Brazil \\ Correspondence: Ricardo de Lima Vasconcelos, Faculdade de Ciências Agronômicas, Universidade Estadual \\ Paulista, Campus Botucatu, Avenida Universitária, no 3780, CEP 18610-034, Altos do Paraíso, Botucatu, SP, \\ Brazil. Tel: 55-014-3880-7165. E-mail: ricardo-matao-sp@hotmail.com
}

Received: March 11, 2019

doi:10.5539/jas.v11n10p217
Accepted: May 19, 2019 Online Published: July 15, 2019

URL: https://doi.org/10.5539/jas.v11n10p217

\begin{abstract}
The Juçara palm is native to the Brazilian Atlantic Forest and has significant commercial and environmental potential. Its multiple end-uses have encouraged studies on its climatic requirements, especially in the state of São Paulo, Brazil, where its presence is currently limited due to illegal exploitation. The objective of this study was to conduct an agroclimatic zoning of the Juçara palm tree in São Paulo. Meteorological data from 110 government stations, the Rural Environmental Registry (CAR) and ArcGIS ${ }^{\circledR} 10.4$ geotechnical tools were used to show temperature, precipitation, and water deficit data in map-like visualizations for reclassified an agroclimatic zoning. A significant proportion of São Paulo State is considered suitable and viable for the Juçara palm, mainly in the south-central and eastern parts of the state and including regions adjacent to large population centers. Considering sufficient economic return, irrigation can be used in regions that are at the lowest limit of the plant's water demand. For areas where the upper-temperature limit exceeds the recommended temperature for the plant, its cultivation/management should be explored as part of agroforestry systems. Based on our analysis, the CAR environmental registry is effective in identifying areas for the implementation of agroforestry systems.
\end{abstract}

Keywords: agroforestry systems, Atlantic forest, geoprocessing, geotechnology, Juçara palm, Rural Environmental Registry (CAR)

\section{Introduction}

Brazil is a large country with significant variation in climatic and productive environments, which allows for the cultivation of a wide range of different crops. For some crops, the country has the advantage of producing more than one harvest per year, such as beans, maize and sugarcane crops.

According to MAPA (2016), the agribusiness sector produced an annual revenue of approximately 86.2 billion dollars. Due to its soil and climatic characteristics, Brazil's territory encompasses extensive and rich biomes that have significant potential for the sustainable use of certain species. Through intercropping with native species that have commercial potential, such systems can help to recover altered ecosystems and reduce the environmental impact of illegal exploitation. In comparison with the revenue generated by agricultural products, forest products provide an annual income of approximately 2.82 billion dollars (MAPA, 2016).

Thus, there are clear opportunities to increase the use of forest resources, whether through balanced extraction from natural stands or as systematized crops. In this context, two issues have arisen from the new forest law in Brazil: the first is a normative change that allows for the implementation of agroforestry systems in environmental protection areas (restoration of legal reserves and permanent preservation areas-APP) on small properties (Law no. 12.651/2012-Art. 21); the second is the Rural Environmental Registry (CAR), a national, digital, public registry that consolidates environmental information about rural properties. It thus provides a database that can be used to monitor, control, and combat deforestation, as well as inform environmental and economic planning (regulated by Normative Instruction MMA n ${ }^{\circ}$, May 5, 2014). 
As such, the database enables the identification of areas that are appropriate for the implementation of agroforestry systems in order to restore ecosystem services in these areas, while also supporting economic development on rural properties. The Juçara palm species (Euterpe edulis Martius), known as palmiteira, ripeira, or içara, has a significant demand and potential for using in agroforestry systems. It plays an important role in forest ecosystems since its fruit attracts insect pollinators and animals that disperse the seeds, thus contributing to the dissemination of other forest species (Epagri, 2016).

When processed, the Juçara palm fruit produces açaí, a fruit pulp with high nutritional value, and heart of palm, whose illegal exploitation of which is the main cause of the limited number of individuals in natural forests. To help minimize illegal harvesting of the palm, one alternative is its use in agroforestry systems (Epagri, 2016). According to Epagri, the palm can be used in APPs and legal reserves, or in commercial areas where they tend to generate greater revenue.

Considering the commercial value of the Juçara palm, it is environmentally, socially and economically important to expand its cultivation to sites that are appropriate for its development. One way to assess such expansion is the use of agroclimatic zoning, a technique widely used in scientific research that considers the most important climatic variables for each crop. The process uses geotechnologies, such as Geographic Information Systems (GIS), to obtain and consolidate detailed information about an area, such as land use, conservation units, relief, and other relevant characteristics.

The use of geotechnologies presents great efficiency in the zoning of diverse crops, among them, the forest ones, such as Tectona grandis L. F., Toona ciliata M. Roem., Azadirachta indica A. Juss. and Bactris gasipaes Kunth. (Klippel et al., 2013).

Commercial cultivation in agroforestry systems would provide additional income for small- or large-scale farms, particularly in the state of São Paulo, which offers a large consumer market for the fruit pulp (açaí) and heart of palm, and a capacity to absorb increases in production. The objective of this study was to conduct an agroclimatic zoning for the Juçara palm in São Paulo State considering available areas for planting as identified through the Rural Environmental Registry (CAR).

\section{Material and Methods}

\subsection{Characteristics of the Area}

Located in the southeastern region of Brazil, São Paulo is one of the country's 26 federal states, bordered by the states of Minas Gerais to the north and northeast, Paraná to the south, Rio de Janeiro to the east, Mato Grosso do Sul to the west, and the Atlantic Ocean to the southeast. According to Cepagri (2016) and based on the Köppen (1936) climate classification, there are seven climatic regions in São Paulo. Four regions belong to Group C, which includes temperate, rainy and hot climates: Cwa (humid temperate with dry winters and hot summers), Cwb (humid temperate with dry winters and mild summers), $\mathrm{Cfa}$ (humid temperate with hot summers), and Cfb (humid temperate with mild summers); and three to Group A, which includes rainy, tropical climates: Aw (tropical with dry winter season), Am (tropical monsoon climate), and Af (rainy, tropical forest climate).

\subsection{Biology and Ecology of Euterpe edulis M.}

Originally, the range of the Juçara palm extended across most of the Brazilian coast (Atlantic Forest), extending inwards until reaching the limits of other biomes. With the increase in timber extraction and industrial and agricultural development (establishment of crops and livestock), its range has been reduced to the coast and small remnants in the inland areas of the state. Because it presents high population density and increased levels of fruit production, the Juçara palm is considered a key species in its ecosystem. Its seeds are food and dispersed by innumerable animals, from birds to mammals, what highlights its importance as a representative of the genus.

The palm is stoloniferous, reaching heights between 10 and $15 \mathrm{~m}$; it has straight, cylindrical, pinnate leaves with large green sheaths about 2 to 2.5 meters long, and black, flesh-fibrous, drupaceous fruits in infructescence (Henderson, 2000). Its distribution occurs across regions with high temperatures and constant humidity, coinciding with Tropical and Subtropical climates, and it is concentrated in areas with consistently high temperatures and humidity year-round (Eiserhardt et al., 2011).

\subsection{Rural Environmental Registry (CAR) and Spatialization of Areas With Potential for Cultivation}

Based on the national register of rural properties (CAR), the information in the databased enables the identification of areas with the potential for conversion or planting in APPs with restricted use, Legal Reserves, forest remnants and other forms of native vegetation, and areas with other previously consolidated use. Recently, CAR data have been used to define areas that can be reforested or have agroforestry systems installed. We used 
the São Paulo Rural Environmental Registry (CAR), which contains environmental information on areas available for planting due to deforestation or non-compliance with legal reserve restoration, forests, remnants of native vegetation, restricted use areas, and areas with other previously consolidated use. The Ministry of Environment, i3GEO (software) by MMA, OpenLayer, provided the shapefile containing the land use information.

\subsection{Spatialization of Meteorological Data (Precipitation and Temperature) and Relief and Land Use Classes}

We developed a database with the historical series data for average annual precipitation and maximum, average, and minimum air temperatures for 110 municipalities (automated meteorological stations), which were then converted to shapefiles.

The data included information from meteorological stations of the National Water Agency (ANA), the National Institute of Meteorology (INMET), and the Integrated Center for Agrometeorological Information (CIIAGRO). The data includes 30 years (1977 to 2016) of monthly average measurements for rainfall, air temperature, actual evapotranspiration, water surplus, and water deficit (Figure 1).

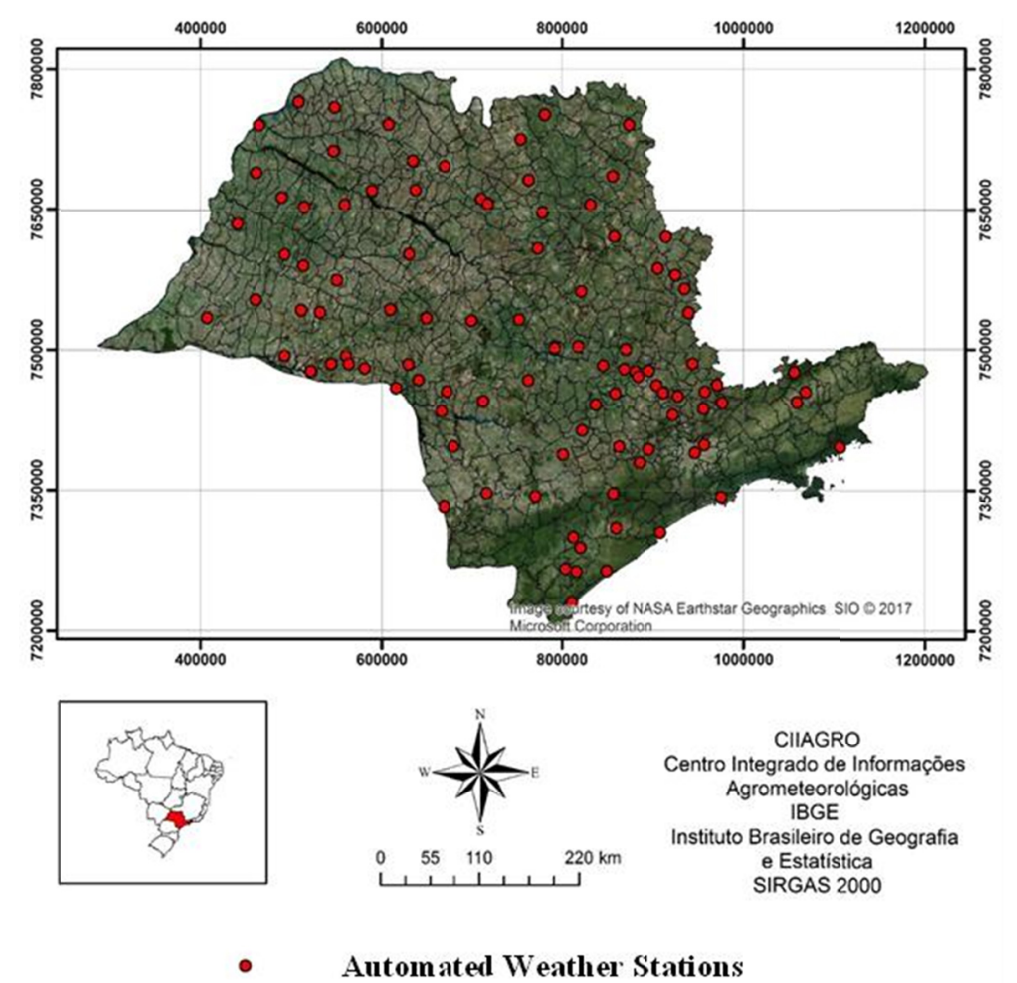

Figure 1. Geographical distribution of meteorological stations in São Paulo

To spatialize the precipitation and temperature data we used two interpolation methods with the Geostatistical Analyst program. The ordinary kriging method was used for annual average precipitation data, and the inverse square of distance was used for the maximum, minimum, and average annual temperature data.

The elevation raster image, or Digital Elevation Model (DEM), was obtained from Embrapa Satellite Monitoring -Brazil in Relief website (Embrapa, 2013), which includes data from NASA's Shuttle Radar Topography Mission (SRTM). The slope values were classified according to the model described in Embrapa (1979), shown in Figure 2. 


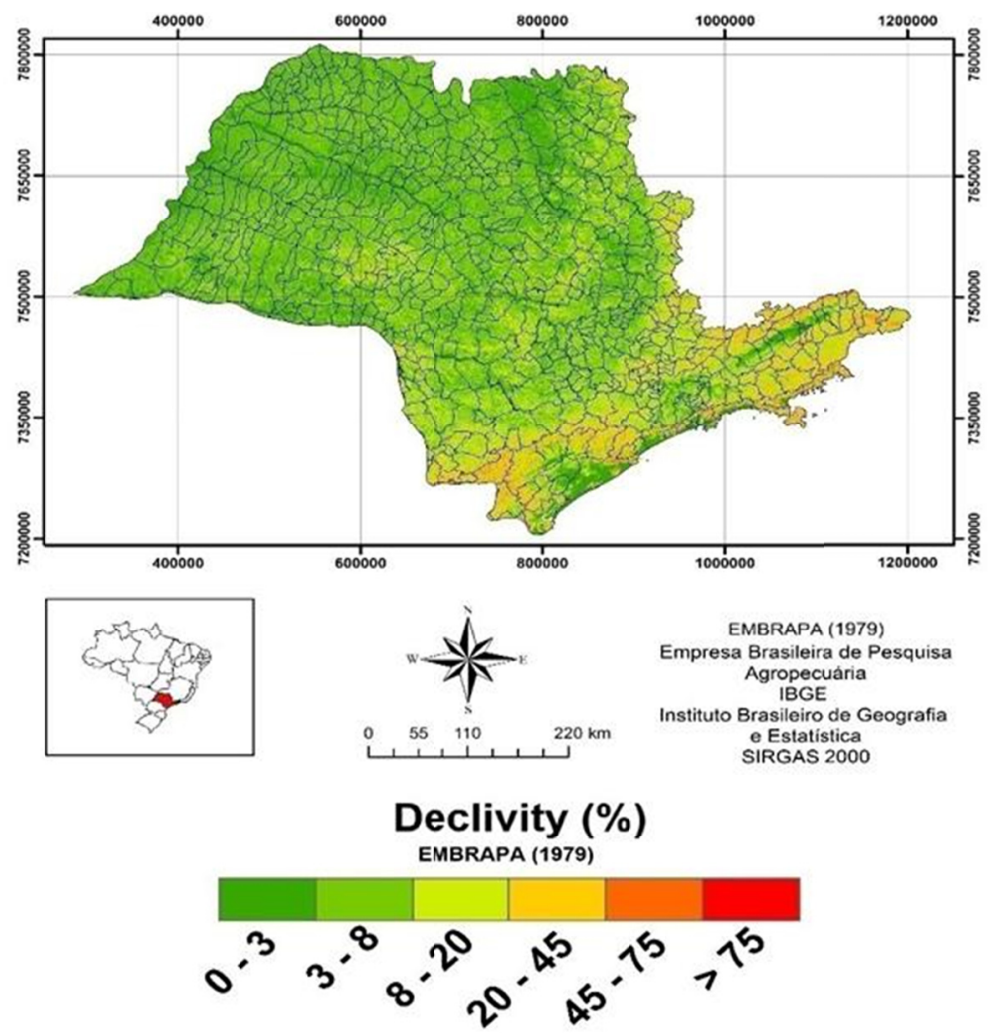

Figure 2. Classification map of declivity as percentage of relief in São Paulo State

The shapefiles containing information on land use in São Paulo was based on the Homogeneous Units of Urban Land Use and Occupancy (UHCT) mapping carried out by the Environmental Secretariat, Government of the State of São Paulo, in partnership with the Geological Institute and financed by the State Fund for Water Resources (FEHIDRO). Land use and land cover data were processed, resulting in the association or combination of particular elements with the landscape, such as physical features, intrinsic shape and texture of the land use.

\subsection{Reclassification of Raster Data and Zoning in São Paulo State}

After the spatialization of the temperature and precipitation variables, the resulting matrix images were reclassified according to crop restrictions for Juçara palm as suggested by Bovi et al. (1987) and Carvalho (1994), shown in Table 1.

Table 1. Crop restrictions according to climatic variables for the state of São Paulo

\begin{tabular}{|c|c|c|}
\hline Class & Precipitation $\left(\mathrm{mm}\right.$ year $\left.^{-1}\right)$ & Temperature $\left({ }^{\circ} \mathrm{C}\right.$ year $\left.{ }^{-1}\right)$ \\
\hline Viable & $1000-2000 \mathrm{~mm}$ & $13-27$ \\
\hline Ideal & $1500 \mathrm{~mm}>x>2200 \mathrm{~mm}$ & $17-26$ \\
\hline Water Restriction & $<1000 \mathrm{~mm}$ & - \\
\hline Temperature Restriction & - & $<13$ or $>27$ \\
\hline
\end{tabular}

Landform slopes classified as Flat (0-3\% slope) or undulating (3-8\% slope) were selected were selected aiming to facilitate the use of agricultural machinery for planting. After the reclassification of the matrix images, the thematic map for zoning was spatialized by combining temperature, precipitation, slope, and CAR data, generating reclassified suitable/unsuitable maps.

Characteristics within the suitable range were given a value of 1 (apt class) and those within the unsuitable range a value of 2 (inapt class). 


\section{Results}

A thematic slope map was generated using ArcGIS 10.4 routines, for we set the maximum slope threshold as $8 \%$. We can see that the majority of São Paulo's relief is suitable for agricultural mechanization, a requirement that is important for the commercial cultivation of Juçara palm. The restricted areas for mechanization are concentrated in the Ribeira and Paraíba Valleys, with a small number of restricted areas along the eastern border with Minas Gerais.

In general, precipitation and temperature values for São Paulo are adequate or slightly below the recommended range for the crop. Through the spatialization of the data for total average precipitation accumulation (Figure 3), the mean values of which ranged from 1082.1 to $2479.1 \mathrm{~mm}$, suitable values occur predominantly in the coastal region.

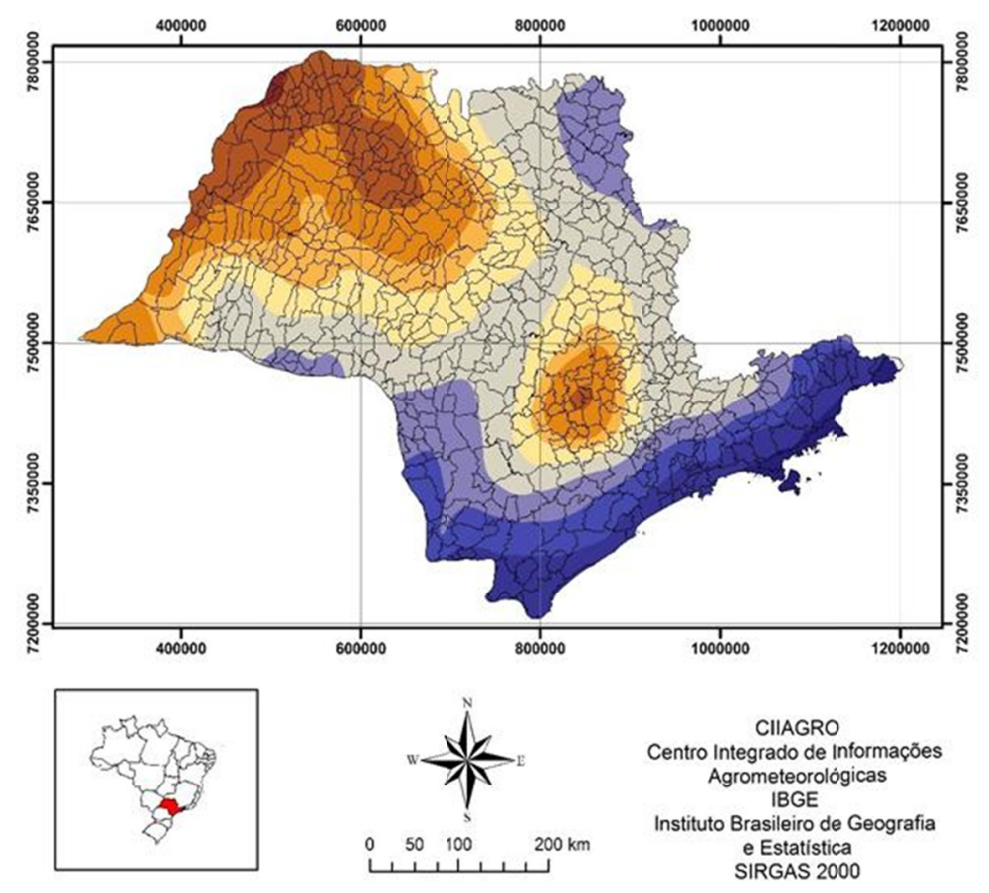

\section{$1082.1 \mathrm{~mm} \square 2479.1 \mathrm{~mm}$}

Figure 3. Map of maximum and minimum monthly precipitation $(\mathrm{mm})$ for the rainy season in São Paulo State

Although continental and maritime influences occur in the state, the average minimum and maximum temperatures for the hottest period (December, January, and February) ranged from 25.3 to $38.5^{\circ} \mathrm{C}$ (Figure 4). 


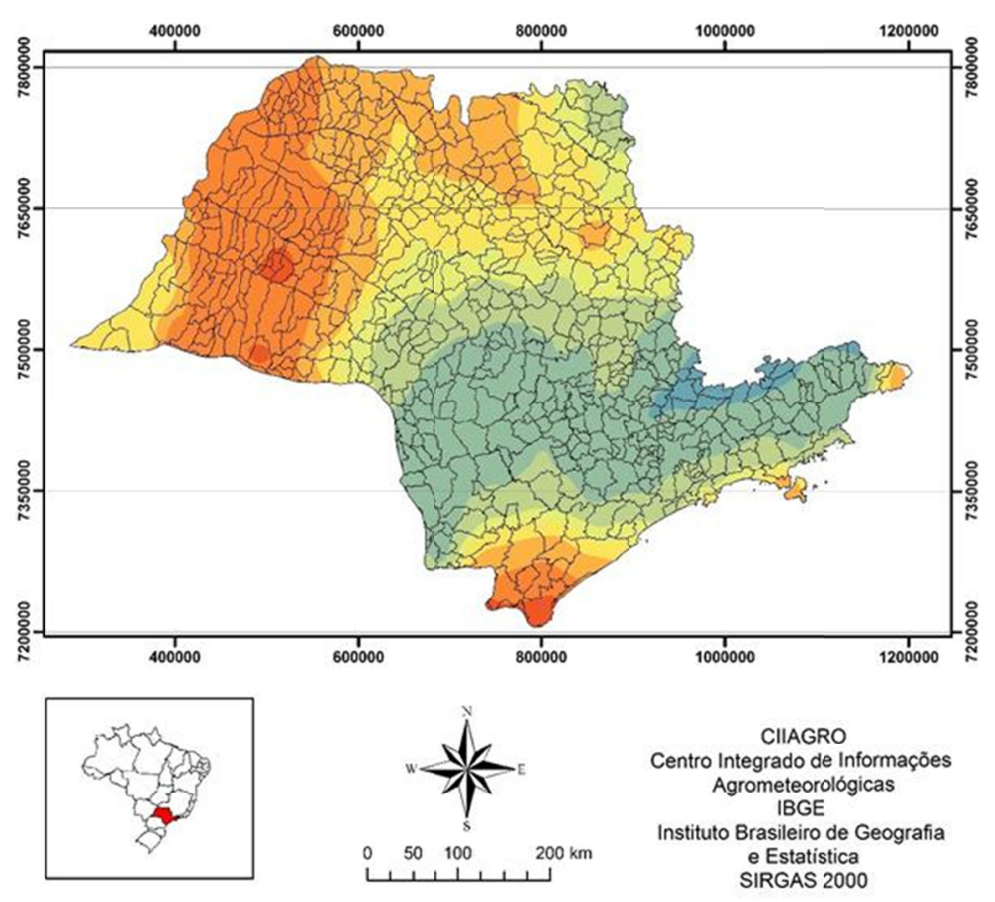

$25.3^{\circ} \mathrm{C} \square 38.5^{\circ} \mathrm{C}$

Figure 4. Map of maximum and minimum monthly temperature $\left({ }^{\circ} \mathrm{C}\right)$ for the hottest period in São Paulo State

In this case, the area restricted for cultivation is more extensive and is concentrated throughout the central-north, east, and west of the state, along with areas in the Ribeira Valley and the coast. The areas with the lowest temperatures are located in the southeast and southwest regions of the state.

The average minimum and maximum temperatures of the coldest period (June, July, and August) in the state range from -2.7 to $-11.5{ }^{\circ} \mathrm{C}$ (Figure 5), and it should be emphasized that colder temperatures also affect the growth and development of the crop. 


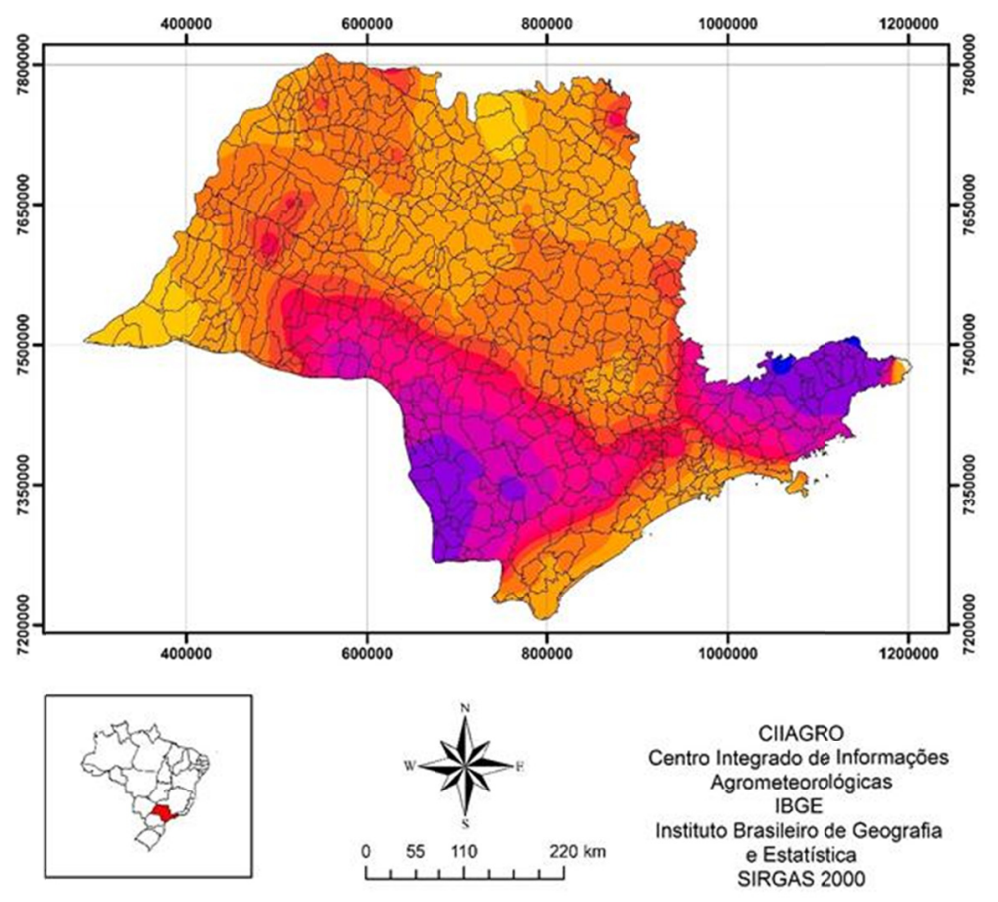

\section{$-2.7^{\circ} \mathrm{C} \square 11.5^{\circ} \mathrm{C}$}

Figure 5. Map of the maximum and minimum monthly temperature $\left({ }^{\circ} \mathrm{C}\right)$ for the coldest period in São Paulo State

The areas that are classified as viable for reforestation in São Paulo based on the CAR database are shown in Figure 6. Within the identified areas, especially the west, center-south, and the Paraíba Valley, there are high levels of vegetation degradation or even deforestation.

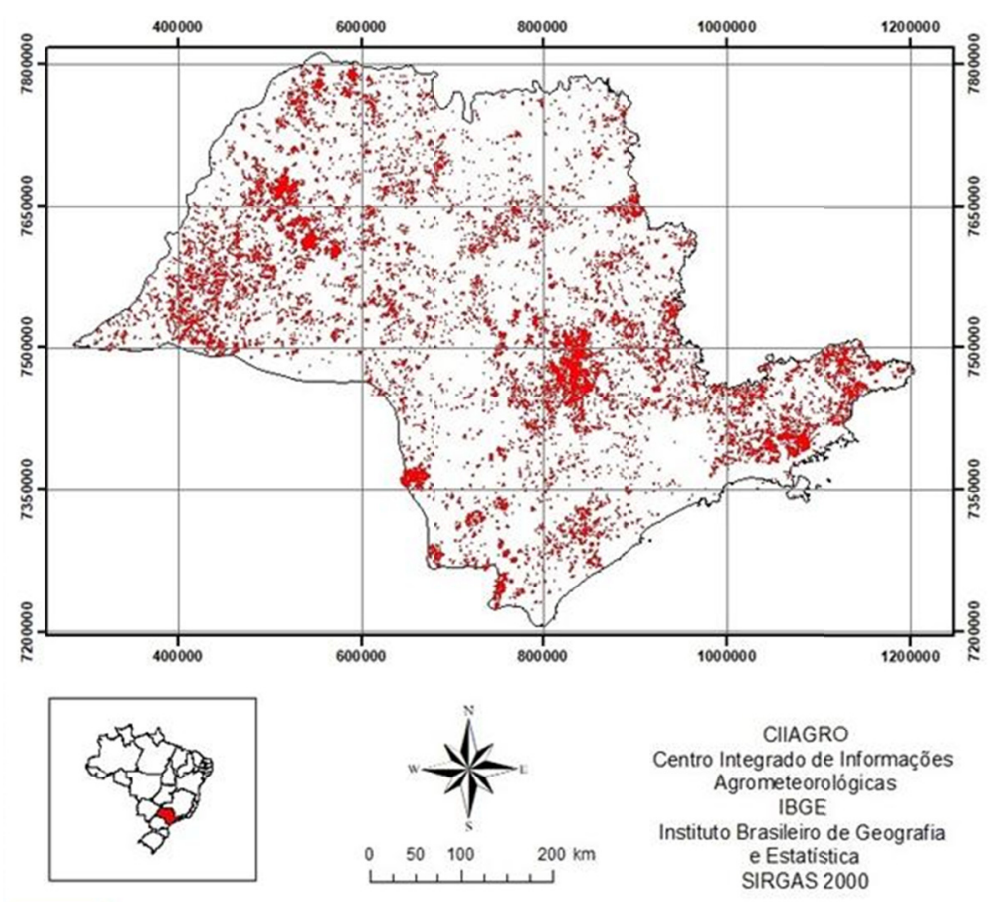

Areas Suitable for Forest Restoration

Figure 6. Areas suitable for reforestation in São Paulo based on the CAR database system 
The agroclimatic zoning maps for the Juçara palm tree in the state of São Paulo are shown in Figures 7 and 8 and are based on the data in the Table 1 .

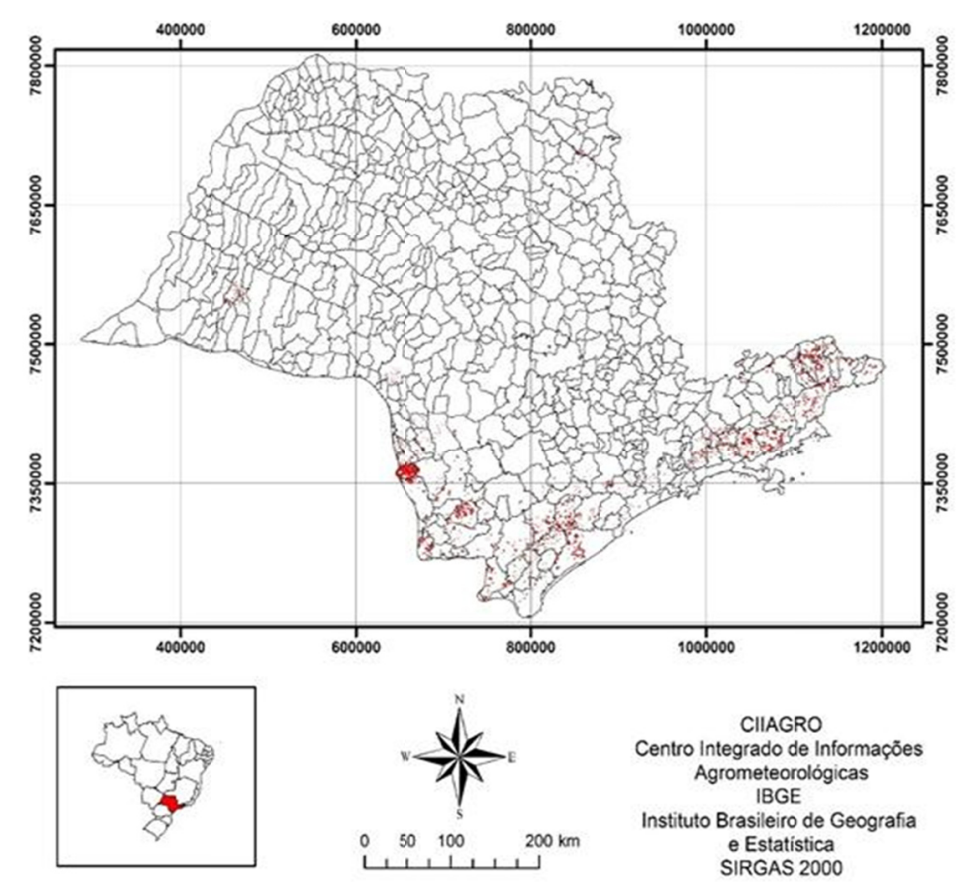

Id eal Areas for Euterpe edulis Mart. cultivation

Figure 7. Agroclimatic zoning of ideal areas for the cultivation of the Juçara palm tree in São Paulo State

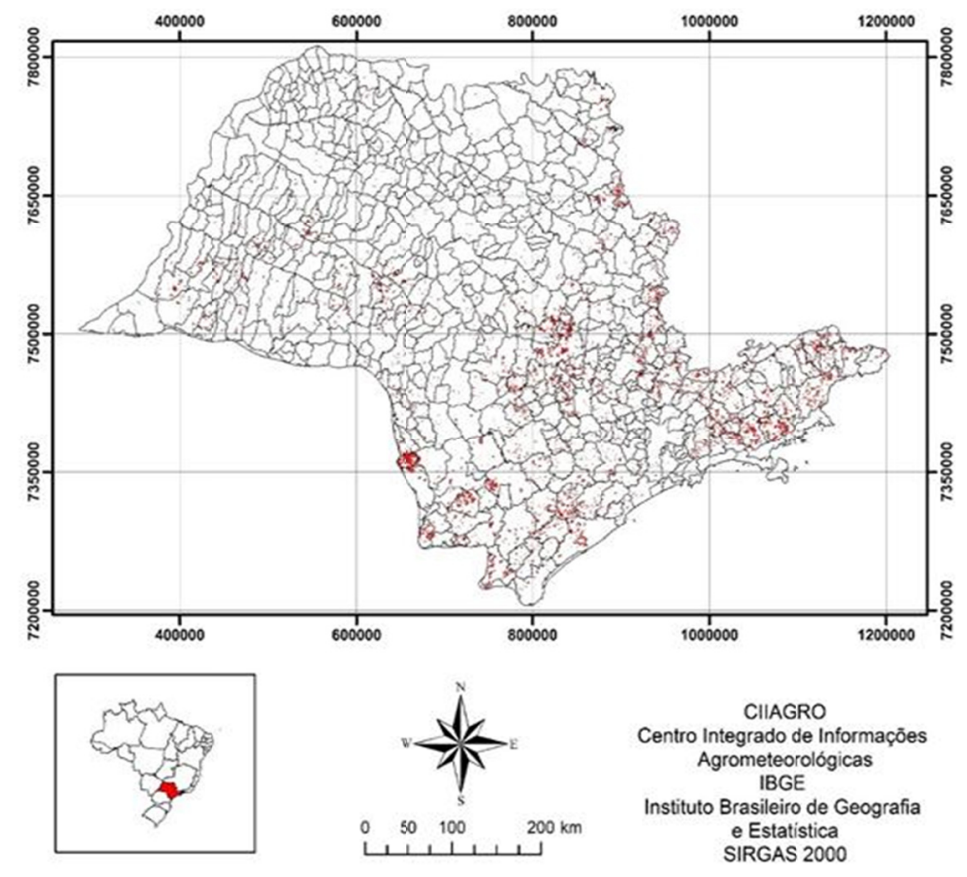

Viable Areas for Euterpe edulis Mart.

Figure 8. Agroclimatic zoning of viable areas for the cultivation of the Juçara palm tree in São Paulo State 
These maps are the result of consolidating and processing data related to precipitation and maximum, medium, and minimum temperatures, slope (up to $8 \%$ ), land use, and areas suitable as identified through CAR.

\section{Discussion}

Although the majority of São Paulo State shows suitable slopes for mechanized cultivation of Juçara palm, there are other factors that affect suitability in relation to slope. According to Pezzopane et al. (2000), in relation to slope is that it affects the level of total solar radiation, thus directly influencing physiological (evapotranspiration and photosynthesis) and edaphoclimatic (heating and cooling of air and soil) parameters. There are examples of sustainable management of the Juçara palm in areas considered restricted based on our results including the Ribeira Valley, within Quilombo communities (Barroso et al., 2010) and on farms (Ribeiro \& Odorizzi, 2000), as well as in the Paraíba Valley, where small-scale farmers produce the palm through small rural agroindustry (Cembraneli et al., 2009).

Besides slope, two of the main limiting factors for the commercial cultivation of the Juçara palm are precipitation and temperature, these two factors are responsible for the vegetal characteristics of a region and they also affect agricultural production.

Due to proximity to the ocean and the leeward wind associated with mountainous regions (coastal region), causes the water vapor contained in the air to condense and precipitate without reaching the inland of the state. This palm tree requires precipitation between 1000 to $2200 \mathrm{~mm}_{\text {year }}{ }^{1}$ and a maximum thermal variation between $13{ }^{\circ} \mathrm{C}$ and $27^{\circ} \mathrm{C}$. Regarding the variation in the average maximum and minimum precipitation for the state, it is important to highlight both the continental and maritime influence.

Under the maritime influence, we can see high average monthly values along the coastal strip of the state and along the southern border with Paraná. The lowest precipitation values occur in the northwest region of the state, reinforcing the continental effect. According to Lorenzi (2014), the Juçara palm is mesophilic (can tolerate average levels of humidity and occasional drought) or slightly hygrophilous (occurring in humid regions).

Except in areas with limited rainfall, the majority of São Paulo is appropriate for the cultivation of this palm. In areas where rainfall is insufficient for cultivation, irrigation can be used, provided that it is economically viable and there is enough water supply. In an economic viability study, Marques and Coelho (2003) concluded that pupunha palm irrigation in the northwest region of the state provided an increase in real productivity of $257 \%$, above the maximum required productivity of $130.3 \%$.

Precipitation values above $1500 \mathrm{~mm}$ that are evenly distributed throughout the year provide suitable conditions for plant development (Carvalho, 1994). This value corresponds to a minimum monthly precipitation of $125 \mathrm{~mm}$, which demonstrates that cultivation of this crop would be unsuitable in the northwest area of the state.

However, considering precipitation of up to $2200 \mathrm{~mm}$ per year, which is suitable for the palm tree according to Bovi et al. (1987), this value is similar to the maximum precipitation that occurs in São Paulo, thus reducing the potential area for cultivation.

When evaluating the harvesting of Juçara palm fruit in the Serra do Mar State Park, SP, and its surroundings, Danielli et al. (2016) found a considerable number of individuals in areas where average annual rainfall ranges from $2300 \mathrm{~mm}$ to $3000 \mathrm{~mm}$, corresponding to a monthly value of 191.6 to $250 \mathrm{~mm}$. These results confirm the palm's capacity to survive and produce in extremely humid areas.

The minimum temperature is higher than the maximum limit of $27^{\circ} \mathrm{C}$ recommended by Carvalho (1994). These observed temperatures may be the result of current climatic conditions which are related to the accumulation of greenhouse gases that retain heat in the atmosphere, one of the factors responsible for this increase. In this context, the use of agroforestry systems may provide a more adequate temperature for cultivation, since the microclimate inside a well conserved forest is lower than that of surrounding areas. For example, Martini and Biondi (2015) found that the temperature of an urban forest in Curitiba, Paraná State, in the summer had a temperature $4.6{ }^{\circ} \mathrm{C}$ lower than the temperature recorded at the same time in a pine forest.

However, based on the precipitation and temperature characteristics of the site, which may affect the growth and development of the plant, Batista et al. (2000) point out that areas suitable for agroforestry must have altitudes below $700 \mathrm{~m}$, with altitudes between $700 \mathrm{~m}$ and $1000 \mathrm{~m}$ being fairly suitable, and altitudes over $1000 \mathrm{~m}$ inappropriate or restricted.

Nevertheless, the use of the Juçara palm was not restricted to agroforestry systems. It may also be used in riparian forests to promote the preservation of the area, while offering benefits from exploitation (Reis, 2012). The region presented a considerable variation in the average maximum and minimum temperatures during the cooler period, 
which according to the literature would restrict cultivation; however, subtropical palm leaves tolerate temperatures between -5 and $-14{ }^{\circ} \mathrm{C}$ without sustaining permanent damage (Larcher, 2003).

In the Atlantic Forest in northeastern Argentina, a mortality rate of $75 \%$ of young Juçara palm plants occurred when exposed to a temperature of $-1.3{ }^{\circ} \mathrm{C}$, followed by five days with temperatures below $0{ }^{\circ} \mathrm{C}$ (Gatti et al., 2008). Studying the distribution of this species in the same region years later, the authors found a reduction in the presence of the plants, possibly due to the intensity and frequency of frosts, which affect photosynthesis and plant growth.

In forests at higher altitudes, the minimum temperatures do not reach levels lower than $4{ }^{\circ} \mathrm{C}$, and studies have shown an abundance of individuals presenting vigorous growth (Gatti et al., 2008). However, we must emphasize that even in forests where low temperatures do not occur, the presence of this species is not uniform, and the species is absent from open gaps (Gatti et al., 2011). Restrictions related to direct solar radiation can be observed for young plants since it is common for adult plants to be exposed to solar radiation (Gatti et al., 2014).

In the southern region of Brazil, where a greater frequency of colder temperatures are observed, there are several regions in which the species is cultivated and harvested (Paludo et al., 2012). However, although the region presents colder temperatures in the winter, it has fewer extremes in temperature variation.

Generally, these conditions are related to the intensity of farming activities, since these regions have been important for economic production within the state, particularly through the cultivation of coffee and sugarcane as well as cattle raising. Therefore, the identified areas represent locations where there is need to establish, maintain, or expand natural vegetation. There is a wide spatial distribution of areas identified by CAR with the potential for growing Juçara palm, particularly in agroforestry systems and agriculture. As such, the CAR database can be an environmental and social tool to promote sustainable production and economic development, particularly for small-scale producers and family farmers.

Based on CAR, Rodrigues (2015) observed that the use of Juçara palm can be implemented in legal reserves to generate income, especially when intercropped with Bactris gasipaes Kunth. (pupunha); this system can provide gains over time, since pupunha requires a longer period for production, and Juçara palm offers a greater commercial value. Rodrigues (2015) notes that the use of CAR provided a level of flexibility that enables producers to establish legal reserve areas with annual revenue generation.

Figure 7 shows that the suitable areas for cultivation and management of the Juçara palm are concentrated along the coast of the state, followed by regions along the borders with Minas Gerais and Paraná. The identification of these areas is a consequence of the microclimatic conditions of these regions that are favorable for the species. The regions considered viable (Figure 8) for planting the Juçara palm cover a large area of the state, with potential growth in the north, east, and central-west. These regions include areas with large population centers that may offer potential consumer markets for both açaí and heart of palm when properly managed and certified.

Considering Figures 3, 7, and 8, rainfall was the main factor that determines the viable and suitable areas for Juçara cultivation. In the north and northeast regions of the state, there are risks related to soil moisture for palm cultivation; however, these risks can be minimized with the adoption of irrigation techniques after a viability analysis. The map of viable areas for the Juçara palm (Figure 8) somewhat follows the distribution of the remaining Atlantic Forest fragments in São Paulo, as confirmed by the data presented in Ponzoni (2011). According to the author, there are areas with high rates of deforestation of this biome in the state, especially in the western, northern, and northeastern regions, which were identified as unsuitable for cultivation in the present study.

Table 2 showed the municipalities with the greatest number of suitable/viable areas for the cultivation of the Juçara palm in the state of São Paulo. Variations in the conditions necessary for viable production of the palm can be related to atmospheric phenomena that are currently producing more intense oscillations in temperature and precipitation, along with anthropogenic activities that are transforming the environment. 
Table 2. Agroclimatic areas appropriate for Juçara palm tree cultivation in the municipalities of São Paulo State

\begin{tabular}{|c|c|c|c|}
\hline Municipality & Area (ha) & Municipality & Area (ha) \\
\hline Adamantina & 57.8 & Itapeva & 219.7 \\
\hline Álvaro de Carvalho & 80.2 & Itapira & 311.5 \\
\hline Amparo & 334.1 & Itapirapuã Paulista & 564.7 \\
\hline Analândia & 67.4 & Itaporanga & 229.9 \\
\hline Anhembi & 86.8 & Itararé & 244.1 \\
\hline Apiaí & 109.7 & Itatiba & 786.4 \\
\hline Areias & 142.4 & Itatinga & 62.7 \\
\hline Atibaia & 113.7 & Itirapina & 179.3 \\
\hline Bananal & 187.0 & Jacareí & 309.8 \\
\hline Barra do Turvo & 542.2 & Jacupiranga & 209.4 \\
\hline Batatais & 67.4 & Jarinu & 96.5 \\
\hline Bofete & 306.1 & Joanópolis & 199.2 \\
\hline Boituva & 80.0 & Juquiá & 811.2 \\
\hline Botucatu & 274.6 & Juquitiba & 60.1 \\
\hline Bragança Paulista & 170.4 & Lagoinha & 66.6 \\
\hline Brotas & 309.6 & Laranjal Paulista & 163.5 \\
\hline Buri & 108.6 & Lavrinhas & 181.7 \\
\hline Cachoeira Paulista & 288.0 & Lorena & 344.8 \\
\hline Caconde & 185.8 & Lucélia & 65.9 \\
\hline Caiabu & 192.2 & Marabá Paulista & 322.7 \\
\hline Caiuá & 61.3 & Marília & 173.9 \\
\hline Cajati & 62.3 & Martinópolis & 59.8 \\
\hline Cajati & 58.7 & Miracatu & 248.4 \\
\hline Cajuru & 150.5 & Mirante do Paranapanema & 93.6 \\
\hline Campinas & 231.3 & Mococa & 55.4 \\
\hline Cananéia & 64.9 & Mogi das Cruzes & 239.4 \\
\hline Canas & 80.4 & Mogi Guaçu & 68.2 \\
\hline Capão Bonito & 381.4 & Mombuca & 153.7 \\
\hline Cássia dos Coqueiros & 153.7 & Monte Mor & 94.3 \\
\hline Charqueada & 353.3 & Monteiro Lobato & 83.7 \\
\hline Conchas & 82.8 & Morungaba & 105.6 \\
\hline Corumbataí & 106.6 & Natividade da Serra & 1310.4 \\
\hline Cristais Paulista & 63.8 & Nova Campina & 131.3 \\
\hline Cruzeiro & 314.2 & Paraibuna & 933.3 \\
\hline Cunha & 780.5 & Patrocínio Paulista & 65.7 \\
\hline Dois Corrégos & 64.0 & Pedra Bela & 75.9 \\
\hline Echaporã & 107.9 & Pedregulho & 132.3 \\
\hline Eldorado & 174.4 & Pedreira & 97.8 \\
\hline Elias Fausto & 205.6 & Pedro de Toledo & 57.3 \\
\hline Espírito Santo do Pinhal & 328.0 & Piacatu & 143.0 \\
\hline Estrela do Norte & 156.1 & Pindamonhangaba & 176.6 \\
\hline Gabriel Monteiro & 73.0 & Piquete & 180.2 \\
\hline Garça & 204.1 & Piracaia & 92.5 \\
\hline Guararapes & 107.2 & Piracicaba & 978.7 \\
\hline Guararema & 292.3 & Piraju & 65.3 \\
\hline Guaratinguetá & 251.0 & Pirajuí & 192.0 \\
\hline Guareí & 159.1 & Pirapozinho & 132.0 \\
\hline Ibiúna & 85.9 & Piratininga & 59.3 \\
\hline Igaratá & 80.8 & Piquerobi & 242.0 \\
\hline Iguape & 927.0 & Pompéia & 239.7 \\
\hline Ipeúna & 196.6 & Presidente Bernardes & 122.7 \\
\hline Iporanga & 517.2 & Presidente Prudente & 137.9 \\
\hline Itaberá & 64.4 & Queluz & 234.9 \\
\hline Itaberá & 92.3 & Rancharia & 77.7 \\
\hline Itaóca & 355.0 & Redenção da Serra & 112.2 \\
\hline Itapetininga & 112.4 & Registro & 391.1 \\
\hline
\end{tabular}




\begin{tabular}{ll|ll}
\hline Municipality & Area (ha) & Municipality & Area (ha) \\
\hline Ribeira & 57.8 & São Luís do Paraitinga & 303.7 \\
Ribeirão Branco & 582.1 & São Manuel & 79.5 \\
Rio Claro & 66.9 & São Miguel Arcanjo & 111.9 \\
Rio das Pedras & 136.6 & São Pedro & 648.0 \\
Riversul & 1142.7 & São Sebastião da Grama & 65.3 \\
Salesópolis & 318.9 & Serra Negra & 66.1 \\
Saltinho & 74.5 & Sete Barras & 377.6 \\
Santa Branca & Silveiras & 455.2 \\
Santa Cruz da Esperança & 175.5 & Taciba & 74.7 \\
Santa Cruz do Rio Pardo & 68.4 & Tambaú & 95.3 \\
Santa Rita do Passa Quatro & 98.8 & Taubaté & 217.9 \\
Santo Antônio da Alegria & 230.2 & Teodoro Sampaio & 100.9 \\
Santo Antônio do Jardim & 65.9 & Tietê & 222.7 \\
Santópolis do Aguapé́ & 78.7 & Torrinha & 97.0 \\
São Bento do Sapucaí & 157.5 & Valinhos & 176.5 \\
São José do Barreiro & 273.2 & Valparaíso & 63.1 \\
São José dos Campos & 383.1 & Vera Cruz & 62.2 \\
\hline
\end{tabular}

In general, the literature suggests that agroforestry systems, independent of the species used, offer a wide range of potential impacts, including socioeconomic ones. Oliveira et al. (2016) showed that an agroforestry system with maize and two legume species, Mimosa caesalpiniifolia, which were tolerant to semiarid conditions, and Gliricidia sepium, a Brazilian caatinga species, provided greater productivity of green maize and consequently higher net income and a reduction in the cost of reforestation.

Furthermore, the agroforestry systems can offer a more adequate and sustainable use of the soil. Rocha et al. (2014) observed that agroforestry systems established with native species present a significant capacity to capture and store carbon in the vegetal biomass and the soil that is similar to native forests. Such systems also have the capacity to recover and improve land use in APPs and legal reserves, thus creating a balance between the local ecosystem and consolidated areas production (Laudares et al., 2017).

\section{Conclusion}

The regions considered suitable and viable for the Juçara palm cover a large area throughout the state of São Paulo, which are located in proximity to large population centers and concentrated in the south and east regions of the state. If revenues from production are sufficient, irrigation in regions that are at the lowest limit of the water demand for the plant can be implemented. In locations where the upper temperature limit exceeds the recommended limit, their cultivation and management should be explored as part of agroforestry systems. The Rural Environmental Registry (CAR) is an important tool to evaluate the environments in rural properties and the database can support the implementation and maintenance of agroforestry systems.

\section{Acknowledgements}

The authors are grateful to the National Council for Scientific and Technological Development (CNPq) for the Post-Doctoral Grant (Process 159000/2018-1) and the Research Productivity Grant (Process 313570/2017-5) that enabled this work to be carried out.

\section{References}

Barroso, R. M., Reis, A., \& Hanazaki, N. (2010). Etnoecologia e etnobotânica da palmeira Juçara (Euterpe edulis Martius) em comunidades quilombolas do Vale do Ribeira, São Paulo. Acta Botanica Brasilica, 2, 518-528. https://doi.org/10.1590/S0102-33062010000200022

Bovi, M. L. A., Godoy Júnior, G., \& Saes, L. A. (1987). Pesquisas com os gêneros Euterpe e Bactris no Instituto Agronômico de Campinas (pp. 1-8). I Encontro Nacional de Pesquisadores em Palmito. Anais... Curitiba: EMBRAPA CNPF.

Carvalho, P. E. R. (1994). Silvicultura de espécies nativas do Brasil (p. 705).

Cembraneli, F., Fisch, S. T. V., \& Carvalho, C. P. (2009). Exploração sustentável da palmeira Euterpe edulis Mart. no Bioma Mata Atlântica, Vale do Paraíba-SP. Revista Ceres, 3, 233-240. 
Cepagri (Centro de Pesquisas Meteorológicas e Climáticas Aplicadas a Agricultura). (2016). Clima dos municipios paulistas. Retrieved from https://orion.cpa.unicamp.br/outras-informacoes/clima-dos-munici pios-paulistas.html

Ciiagro (Centro Integrado de Informações Agrometeorológicas). (2016). Retrieved from http://www.ciiagro. sp.gov.br/ciiagroonline

Danelli, M. F., Fisch, S. T. V., \& Vieira, S. A. (2016). Análise da estrutura e biomassa florestal de áreas de colheita de frutos de Juçara (Euterpe edulis Mart.) no litoral norte e Serra do Mar-SP. Ciência Florestal, 3, 773-786. https://doi.org/10.5902/1980509824206

Eiserhardt, W. L., Svenning, J., Kissling, W. D., \& Balslev, H. (2011). Geographical ecology of the palms (Arecaceae): determinants of diversity and distributions across spatial scales. Annal of Botany, 108, 1391-1416. https://doi.org/10.1093/aob/mcr146

Embrapa (Empresa Brasileira de Pesquisa Agropecuária). (1979). Serviço Nacional de Levantamento e Conservação de Solos (Súmula da 10). Reunião Técnica de Levantamento de Solos. Rio de Janeiro, RJ.

Embrapa (Empresa Brasileira de Pesquisa Agropecuária). (2016). Brasil em relevo. Retrieved from http://www.relevobr.cnpm. embrapa.br

Epagri (Empresa Catarinense de Pesquisa Agropecuária e Extensão Rural de Santa Catarina). (2016). Levantamento Socioambiental-Inventário Florístico Florestal de Santa Catarina. Percepções sobre o uso de conservação. Palmeira, Juçara. Retrieved from http://ciram.epagri.sc.gov.br/ciram_arquivos/arquivos/iff/.../ socioambiental/.../b_jucara.pdf

Gatti, M. G., Campanello, P. I., \& Goldstein, G. (2011). Growth and leaf production in the tropical palm Euterpe edulis: light conditions versus developmental constraints. Flora, 8, 742-748. https://doi.org/10.1016/ j.flora.2011.04.004

Gatti, M. G., Campanello, P. I., Montti, L., \& Goldstein, G. (2008). Frost resistance in the tropical palm Euterpe edulis and its pattern of distribution in the Atlantic Forest of Argentina. Forest Ecology Management, 256, 633-640. https://doi.org/10.1016/j.foreco.2008.05.012

Gatti, M. G., Campanello, P. I., Villagra, M., Montti, L., \& Goldstein, G. (2014). Hydraulic architecture and photo inhibition influence spatial distribution of the arborescent palm Euterpe edulis in subtropical forests. Tree Physiol, 34, 630-639. https://doi.org/10.1093/treephys/tpu039

Henderson, A. (2000). The genus Euterpe in Brazil. In M. S. Reis, \& A. Reis (Eds.), Euterpe edulis Martius (palmiteiro): Biologia, Conservação e Manejo (pp. 1-22). Itajaí: Herbário Barbosa Rodrigues.

Klippel, V. H., Pezzopane, J. E. M., Pezzopane, J. R. M., Cecílio, R. A., Castro, F. S., \& Pimenta, L. R. (2013). Zoneamento climático para teca, cedro australiano, nim indiano e pupunha no estado do Espírito Santo. Floresta, 43, 671-680. https://doi.org/10.5380/rf.v43i4.30914

Köppen, W. (1936). Das geographische System der Klimate. In W. Köppen, \& R. Geiger (Eds.), Handbuch der Klimatologie (pp. 1-44). Berlin, Germany.

Larcher, W. (2003). Physiological plant ecology (p. 514). Springer Verlag, Berlin, Germany. https://doi.org/ 10.1007/978-3-662-05214-3

Laudares, S. S. A., Borges, L. A. C., Ávila, P. A., Oliveira, A. L., Silva, K. G., \& Laudares, D. C. A. (2017). Agroflorestry as a sustainable alternative for enviromental regularization of rural consolited occupations. CERNE, 23, 161-174. https://doi.org/10.1590/01047760201723022240

Lorenzi, H. (2014). Árvores brasileiras: Manual de identificação e cultivo de plantas arbóreas nativas do Brasil (p. 384). Nova Odessa: Instituto Plantarum.

MAPA (Ministério da Agricultura. Pecuária e Abastecimento). (2016). Retrieved from http://www.agricultura. gov.br/agroestatisticas/estatisticas-e-dados-basicos-de-economia-agricola/estatisticas-e-dados-basicos-de-ec onomia-agricola-dezembro-2015.pdf/view.

Marques, P. A. A., \& Coelho, R. D. (2003). Estudo da viabilidade econômica da irrigação da pupunheira (Bactris Gasipaes H. B. K.) para Ilha Solteira-SP. Brasil. Ciência Rural, 2, 291-297. https://doi.org/ 10.1590/S0103-84782003000200017

Martini, A., \& Biondi, D. (2015). Microclima e conforto térmico de um fragmento de floresta urbana em Curitiba, PR. Floresta e Ambiente, 22, 182-193. https://doi.org/10.1590/2179-8087.082114 
Oliveira, V. R., Silva, P. S. L., Paiva, H. N., Pontes, F. S. T., \& Antônio, R. P. (2016). Growth of arboreal leguminous plants and maize yield in agroforestry systems. Revista Árvore, 40, 679-688. https://doi.org/ 10.1590/0100-67622016000400011

Paludo, G. F., Silva, J. Z., \& Reis, M. S. (2012). Estimativas de produção de frutos de palmiteiro (Euterpe edulis Mart.) a partir da densidade de indivíduos. Biodiversidade Brasileira, 2, 92-102.

Pezzopane, E. M., Ribeiro, A., Reis, G. G., \& Reis, M. G. F. (2000). Balanço de radiação em uma floresta em função da declividade e orientação das encostas. Congresso Brasileiro de Meteorologia, 11. Anais... Rio de Janeiro-RJ.

Ponzoni, F. J. (2009). Atlas dos Remanescentes Florestais da Mata Atlântica. Retrieved from http:/www.sigam.ambiente.sp.gov.br/sigam3/Repositorio/222/Documentos/EPBio/EPBio_20_Flavio.pdf

Reis, T. (2012). Zoneamento ambiental para a palmeira Juçara com foco na produção de frutos: potencialidades para a agricultura familiar (111f., Dissertação, Mestrado em Agroecossistemas, Universidade Federal de Santa Catarina, Centro de Ciências Agrárias).

Ribeiro, R. J., \& Odorizzi, J. (2000). Um caso de manejo em regime de rendimento sustentado do palmiteiro na Fazenda Nova Trieste, Eldorado, SP. Sellowia, 49-52, 245-255.

Rocha, G. P., Fernandes, L. A., Cabacinha, C. D., Lopes, I. D. P., Ribeiro, J. M., Frazão, L. A., \& Sampaio, R. A. (2014). Characterization and carbon storage of agroforestry systems in Brazilian savannas of Minas Gerais, Brazil. Ciência Rural, 44, 1197-1203. https://doi.org/10.1590/0103-8478cr20130804

Rodrigues, E. H. P. (2015). Espécies florestais para o uso econômico na reserva legal e propostas de modelos para implementação.

\section{Copyrights}

Copyright for this article is retained by the author(s), with first publication rights granted to the journal.

This is an open-access article distributed under the terms and conditions of the Creative Commons Attribution license (http://creativecommons.org/licenses/by/4.0/). 